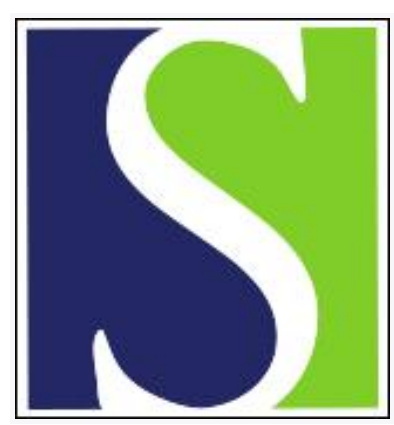

Scand J Work Environ Health 1992;18(6):376-387

https://doi.org/10.5271/sjweh.1559

Issue date: 01 Dec 1992

Temporary health effects from exposure to water-borne paints.

by Ulfvarson U, Alexandersson R, Dahlqvist M, Ekholm U, Bergstrom B, Scullman J

Affiliation: Department of Work Science, Royal Institute of Technology, Stockholm, Sweden.

This article in PubMed: www.ncbi.nlm.nih.gov/pubmed/1485163

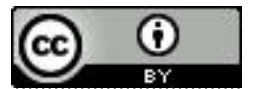




\title{
Temporary health effects from exposure to water-borne paints
}

\author{
by Ulf Ulfvarson, PhD, Rolf Alexandersson, MD, Monica Dahlqvist, PhD, Ulla Ekholm, \\ Björn Bergström, Jan Scullman, MSc ${ }^{1}$
}

\begin{abstract}
ULFVARSON U, ALEXANDERSSON R, DAHLQVIST M, EKHOLM U, BERGSTRÖM B, SCULLMAN J. Temporary health effects from exposure to water-borne paints. Scand $J$ Work Environ Health 1992;18:376-87. Temporary health effects of exposure to experimental paints were studied. Ten painters feeling nuisance from water-borne paints and eight painters not feeling such nuisance applied eight experimental water-borne paints according to normal work routines. The effects were a decrease in forced vital capacity, forced expiratory volume in $1 \mathrm{~s}$ and peak expiratory flow, an increase in urine excretion, and a decrease in urine density. A small, but statistically highly significant, increase in the mean volume of erythrocytes was observed. The effects were similar in the two groups, but the "nuisance group" reacted with a larger urine excretion and a larger increase in the mean volume of erythrocytes. The effects did not influence physical work capacity. The effects on the lungs and urinary excretion were probably not associated with the organic solvents or ammonia in the paints. Instead, they were probably due to derivatives of isothiazolinone. This assumption needs verification.
\end{abstract}

Key terms: blood pressure, forced vital capacity, isothiazolinones, lung function, mean volume of erythrocytes, organic solvents, peak expiratory flow, preservatives, urination.

The work environment of house painters has been debated for a long time, and this trade has had recruitment difficulties. Besides, many house painters leave the trade too early. One reason is the fear of chronic effects on the brain because of exposure to organic solvents $(1,2)$. The use of water-borne paints should reduce or eliminate exposure to organic solvents, and nowadays, in Sweden, water-borne paints are used for most construction painting.

Water-borne paints are mainly emulsion paints based on synthetic polymers, so-called latex paints. They have polyvinyl acetate as a binder or acrylate and copolymers for especially demanding purposes (eg, on joinery products). The latex paints contain water, but there are some volatile organic compounds as well. Small amounts (ie, tenths of a percent) of monomer residues may be present after the polymerization reaction (eg, vinyl acetate and butyl acrylate) (3). The paint manufacturers add organic solvents, usually glycols, glycol ethers, and esters, to promote the film formation process and to improve the application properties. The proportion of solvents has to be higher when the demand for gloss and abrasion resistance is high. The solvent contents are $\leq 2 \%$ in wall paints and $7-8 \%$ in paints for joinery products, sometimes even more than $10 \%$ (3).

Latex emulsions can be a favorable substrate for the growth of microorganisms. Therefore, preservatives have to be added. Paint manufacturers often use mix-

\footnotetext{
1 Department of Work Science, Royal Institute of Technology, Stockholm, Sweden.
}

Reprint requests to: Dr U Ulfvarson, Department of Work Science, Royal Institute of Technology, S-100 44 Stockholm, Sweden. tures of derivatives of isothiazolinone, marketed under various trade names, for this purpose. This group of substances may cause allergic reactions (3-8). Fungicides can also be added to prevent the growth of fungi on paints used in wet rooms.

Most latex paints contain ammonia to adjust the $\mathrm{pH}$ to 8-9 (3). Some amines can be added to certain paints or raw materials, partly for $\mathrm{pH}$ adjustment and partly to improve the emulsion of oils and alkyds in water.

The use of water-borne paints can decrease or eliminate some of the health hazards met when paints with an organic solvent base are used. Yet water-borne paints can involve other problems related to health. These problems are attracting increasing attention as experience accumulates. House painters complain about symptoms or effects from the use of water-borne paints (eg, contact eczema, bad smell from the paints, symptoms from the mucous membranes, headache, stomach disorders, and an unusual need to urinate).

Askergren et al (9) investigated two groups of house painters in the construction industry. One group mainly used water-borne paints, and the other group mainly used ordinary solvent-based paints. The levels of exposure to volatile substances were low according to hygienic standards. The group exposed mainly to solvent-based paints suffered from effects on the peripheral nervous system. The painters mainly working with water-borne paints did not show these effects. Both groups experienced some effects on the kidneys and the urinary tract. Such effects have previously been reported after exposure to organic solvents. The numbers of leucocytes and thrombocytes were lower in the group mainly exposed to water-borne paints. The authors did not suggest any components in the paints that could have caused the observed effects. Chroni- 
cally increased erythrocyte volume has also been reported for house painters using epoxy resins and for car repair painters $(10,11)$.

The purpose of the present study was to investigate symptoms of the kind reported and other acute, temporary health effects of exposure to water-borne paints. Another purpose was to identify components that could cause such effects. The ultimate purpose was to provide information that would aid the elimination of hazardous substances from water-borne paints through product modification.

\section{Materials and methods}

\section{Experimental design}

We investigated eight different paint products in the following experiment. Eighteen house painters applied one paint during a day at a normal work rate for professional painters. The painters applied all paints in a normal, professional way for wall and ceiling paints, with a roller on plaster boards mounted on the walls and the ceiling of a big room of normal height. The experimental room had a floor surface of $488 \mathrm{~m}^{2}$ and a surface for painting (walls and ceiling) of 990 $\mathrm{m}^{2}$. As the space in the experiment room was limited and did not allow all of the painters to work simultaneously, the study of each paint was repeated twice with nine painters each time, five from the "nuisance group" and four from the "nonnuisance group." (See the following section.) The repeated studies also created a possibility for checking that the repetitions did not interact with the results. There was only natural ventilation in the room, with a specific flow rate of $1-2 \mathrm{~m}^{3} \cdot \mathrm{m}^{-3} \cdot \mathrm{h}^{-1}$. The painting continued for $5-6 \mathrm{~h}$, a normal period of effective work during a workday. We carried out all of the experiments on Mondays so that the painters would have had an exposure-free period before the experiment. We subjected the painters to a medical examination on the Monday before the main investigation. The purpose of this first examination was to establish base-line values for the effect variables.

We asked the painters to live normally during the study (ie, to drink and eat as usual). The painters had breaks and ate and drank in the same way on all of the experimental days.

\section{Inquiry and selection of examined workers}

We sent a postal inquiry about health-related disorders to all members of the painters' trade union in one region of Sweden, altogether 250 workers. Twelve workers could not be reached at all because they were working abroad. The number of painters responding was 203 , or $85 \%$ of those who received the inquiry. The subjects excluded from further investigation were those with earlier or present diseases of possible importance to the results of the investigation, for in- stance, diseases of the heart, lungs, or kidneys, and those who took drugs.

The painters were also asked: "Do you experience nuisance when working with a particular paint or product?" We selected 10 subjects for the "nuisance group" from the painters who felt nuisance from exposure to water-borne paints. Another eight subjects were selected for the "nonnuisance group" from painters who did not feel nuisance when working with water-borne paints. In this way we wanted to study whether experienced nuisance from exposure to waterborne paints could be confirmed by measurable medical effects and whether painters that feel nuisance from work with paint products reacted objectively in any different way than painters that do not feel nuisance. All 18 of the subjects were men between 19 and 57 years of age, with an average age of 36 years. Three subjects were smokers, two in the nuisance group and one in the nonnuisance group.

\section{Medical methods}

Initial examination. We examined the 18 subjects medically, starting with a questionnaire. The first clinical examination, carried out on a Monday morning, concentrated on diseases or disorders of the heart and lungs, allergies, and sensitization reactions of the airways and skin. Disorders of mucous membranes of the eyes, nose, mouth, and throat and subjective disorders from the airways and lungs were noted as well. A morning sample of urine (first excreted urine) was analyzed with indicator paper for albumin and glucose. The density was measured as well. For the base-line values, venous blood was sampled after fasting since 2400 the night before. The blood samples were analyzed in a department of clinical chemistry according to routine methods. The blood status was determined from counts of leucocytes, erythrocytes, reticulocytes, and thrombocytes and from the determined hemoglobin concentration. For the erythrocytes the volume fraction, the mean corpuscle volume, the content of hemoglobin, and the mean corpuscle concentration of the hemoglobin were also determined. Liver status was characterized by values for bilirubin and the enzymes in serum, aspartate aminotransferase, and alanine aminotransferase. Finally the plasma content of haptoglobin and immunoglobulins (IgE, IgA, IgM, IgG) was determined.

Dynamic spirometry was carried out on the afternoon of the first Monday with a Vitalograph ${ }^{\circledR}$ COMPACT (Kebo-Care) calibrated with a volume of 51 using a 1-1 precision syringe, before and after each experiment. All of the variations between calibrations were less than $3 \%$. The spirometric examinations gave values for forced vital capacity (FVC, liters) and forced expiratory volume in $1 \mathrm{~s}\left(\mathrm{FEV}_{1.0}\right.$, liters), as described by Cotes et al (12). Peak expiratory flow (PEF) was measured as well. We instructed the subjects to make a maximal inhalation and then to exhale as fast and 
as completely as possible. At least three determinations were carried out, and the measurement was not considered successful unless the two highest FVC values did not differ by more than $5 \%$. In the case of all of the variables the highest value was used. The volumes were corrected to conditions of body temperature and pressure, saturated with water vapor (BTPS) (13).

Electrocardiography was carried out with disposable electrodes and with the subject in a horizontal position. The examination was made in a department of clinical physiology according to standard procedures with a portable apparatus, SICARD 440 (SiemensElema). The apparatus could store up to 10 electrocardiograms. These electrocardiograms were transferred to a minicomputer (PDP) for computer-based signal analyses. A clinical physiologist with long-term experience with electrocardiograms scrutinized the electrocardiograms with reference to the Minnesota code (14). He had no knowledge of the experimental situation.

The systolic and diastolic blood pressure was measured after $10 \mathrm{~min}$ of rest, with the subject in a sitting position and according to standard procedures. The mean blood pressure was calculated according to the following formula: (diastolic blood pressure) $+(1 / 3)$ [(systolic blood pressure)-(diastolic blood pressure)].

The circumference of the subject's abdomen was measured with a tape measure at navel level, with the subject stripped to the waist and asked to relax. Any change in this variable was presumed to indicate gas formation in the gastrointestinal system.

\section{Examinations during the experiments}

The following examinations and measurements were repeated in the whole series of experiments. Headache and symptoms from the eyes, stomach, urinary tract, airways and lungs, and heart were noted according to a standard protocol before and after the workdays.
Blood status, liver status, and the content of haptoglobin and immunoglobulins in plasma (as described for the base-line values), dynamic spirometry, electrocardiography, and blood pressure were determined in the afternoons, within $30 \mathrm{~min}$ of the end of the exposure. The excreted volume of urine was measured during the exposure to experimental paints. The subject emptied his bladder immediately before he started painting. The urine excreted thereafter during the experiment was collected in a 2-l vessel. The volume of sampled urine was measured, and the density was tested in a clinical-chemical laboratory. The circumference of the subject's abdomen was measured with a tape measure at the navel level after each exposure.

\section{Contents of the paint products}

A leading paint manufacturer supplied the eight experimental paints in cans of either 12 or 41 , owing to the type of paint (table 1). The nature of the paints used in the experiments is presented in table 1 . In tables 2-4 the declared contents of the paints are presented as well.

\section{Exposure measurements}

Personal and stationary, full-period, consecutive sampling for the measurement of air contaminants was carried out. To collect dust particles, we used the filter method. Air was pumped through cellulose acetate filters in $25-\mathrm{mm}$ cassettes for $5-6 \mathrm{~h}$ with an airflow of about $21 \cdot \mathrm{min}^{-1}$. Aerosol drops were collected on glass fiber filters.

Ammonia or triethyl amine was sampled on filters impregnated with phosphoric acid $(15,16)$ in $37-\mathrm{mm}$ cassettes, for 3-4 h, with an airflow of about $1 \mathrm{l}$. $\mathrm{min}^{-1}$ and analyzed by high-performance liquid chromatography using an ultraviolet detector system. Organic solvents (hexylene glycol, Texanol ${ }^{\circledR}$, propylene glycol, Dalpad $\mathbf{A}^{\circledR}$ ) were sampled for periods of

Table 1. Type of paints, the can size in liters, the consumption of paints (liters/person and shift) and the average time-weighted aerosol concentration during application of the paints.

\begin{tabular}{|c|c|c|c|c|c|}
\hline \multirow[t]{2}{*}{ Paint } & \multirow[t]{2}{*}{ Type of binder } & \multirow{2}{*}{$\underset{(I)}{\text { Can size }}$} & \multirow{2}{*}{$\begin{array}{c}\text { Average } \\
\text { consumption } \\
\text { (I/person } \\
\text { and shift) }\end{array}$} & \multicolumn{2}{|c|}{$\begin{array}{l}\text { Aerosol } \\
\text { concentration } \\
\left(\mathrm{mg} / \mathrm{m}^{3}\right)\end{array}$} \\
\hline & & & & Average & SD \\
\hline 1 & Wall paint: polyvinyl acetate - eten & 12 & 36.0 & 0.31 & 0.13 \\
\hline 2 & Wall paint: polyvinyl acetate - eten & 12 & 39.0 & 0.25 & 0.06 \\
\hline 3 & Wall paint: polyvinyl acetate homopolymer & 12 & 40.0 & 0.35 & 0.08 \\
\hline 4 & Wall paint: polyvinyl acetate - butyl acrylate & 12 & 35.3 & 0.36 & 0.06 \\
\hline 5 & Joinery products paint: ethyl methyl metacrylate & 4 & 29.0 & 0.49 & 0.09 \\
\hline 6 & $\begin{array}{l}\text { Joinery products paint: acrylate co-polymer: styrene methyl } \\
\text { metacrylate and acrylic nitrile }\end{array}$ & 4 & 27.4 & 0.42 & 0.10 \\
\hline 7 & $\begin{array}{l}\text { Top coat for walls and ceilings in bathrooms: acrylate } \\
\text { copolymer: butyl metacrylate and methyl metacrylate } \\
\text { acrylic acid }\end{array}$ & 12 & 30.3 & 0.41 & 0.17 \\
\hline 8 & Primer: alkyd emulsion & 12 & 22.7 & 0.48 & 0.13 \\
\hline
\end{tabular}


Table 2. Content of organic solvents in the paints (according to the declaration) and the time-weighted average concentrations in the inspired air of the subjects.

\begin{tabular}{|c|c|c|c|c|c|c|c|c|c|}
\hline & \multicolumn{2}{|c|}{ Hexylene glycola } & \multicolumn{2}{|c|}{ Texanolb } & \multicolumn{2}{|c|}{ Propylene glycolc } & \multicolumn{2}{|c|}{ Dalpad $A^{d}$} & \multirow{2}{*}{$\begin{array}{c}\text { Lusolvan } \\
\mathrm{FBH}^{\mathrm{e}} \\
\text { (Average) }\end{array}$} \\
\hline & Average & SD & Average & SD & Average & SD & Average & SD & \\
\hline Paint 1 & - & $\cdot$ & - & $\cdot$ & - & $\cdot$ & - & $\cdot$ & - \\
\hline \multicolumn{10}{|l|}{ Paint 2} \\
\hline $\begin{array}{l}\text { Paint (\%) } \\
\text { Air (ppm) }\end{array}$ & $\begin{array}{l}1.16 \\
1.99\end{array}$ & 0.77 & - & . & - & . & - & . & - \\
\hline \multicolumn{10}{|l|}{ Paint 3} \\
\hline $\begin{array}{l}\text { Paint (\%) } \\
\text { Air (ppm) }\end{array}$ & $\begin{array}{l}1.16 \\
3.02\end{array}$ & 1.85 & - & : & - & : & - & $\dot{.}$ & - \\
\hline \multicolumn{10}{|l|}{ Paint 4} \\
\hline $\begin{array}{l}\text { Paint (\%) } \\
\text { Air (ppm) }\end{array}$ & $\begin{array}{l}2.7 \\
7.28\end{array}$ & 1.64 & $\begin{array}{l}0.4 \\
0.83\end{array}$ & 0.28 & - & . & - & . & $\overline{-}$ \\
\hline \multicolumn{10}{|l|}{ Paint 5} \\
\hline $\begin{array}{l}\text { Paint (\%) } \\
\text { Air (ppm) }\end{array}$ & $3 . \overline{67}$ & 1.59 & - & . & $\begin{array}{r}8.2 \\
11.5\end{array}$ & 4.5 & $\begin{array}{l}0.89 \\
0.42\end{array}$ & 0.29 & $\overline{-}$ \\
\hline \multicolumn{10}{|l|}{ Paint 6} \\
\hline $\begin{array}{l}\text { Paint }(\%) \\
\text { Air (ppm) }\end{array}$ & $2 . \overline{72}$ & 0.99 & $\begin{array}{l}4.3 \\
5.2\end{array}$ & 2.4 & $\begin{array}{r}8.1 \\
17.3\end{array}$ & 5.5 & $\overline{-}$ & . & $\overline{-}$ \\
\hline \multicolumn{10}{|l|}{ Paint 7} \\
\hline $\begin{array}{l}\text { Paint (\%) } \\
\text { Air (ppm) }\end{array}$ & $\begin{array}{l}0.5 \\
2.62\end{array}$ & 0.87 & $2 . \overline{47}$ & 2.59 & - & . & $\begin{array}{l}2.0 \\
0.50\end{array}$ & 0.08 & $\begin{array}{l}2.6 \\
\cdots\end{array}$ \\
\hline \multicolumn{10}{|l|}{ Paint 8} \\
\hline $\begin{array}{l}\text { Paint }(\%) \\
\text { Air }(\mathrm{ppm})\end{array}$ & $3 . \overline{37}$ & 0.41 & $0 . \overline{74}$ & 0.04 & - & : & $0 . \overline{78}$ & 0.07 & - \\
\hline
\end{tabular}

a 2,4-Dihydroxy-2-methylpentane (CAS 107-41-5).

b 2,2,4-Trimethyl-1,3-pentandiolisobutyrate (CAS 25265-77-4).

c 1,2-Propandiol (CAS 57-55-6).

d 2-(2-Phenoxyethoxy)ethanol (CAS 104-68-7).

e A mixture of dicarbonic acid esters of isobutanol (manufacturer BASF).

30 min to about $2 \mathrm{~h}$ in tuhes filled with active carbon or Amberlite XAD-7, with an airflow of about $0.21 \cdot \mathrm{min}^{-1}$.

The solvents sampled with carbon tubes were desorbed with $1.5 \mathrm{ml}$ of carbon disulfide and determined by gas chromatography (Hewlett-Packard 5790), equipped with a flame ionization detector and a DB5 fused silica column (internal diameter $25 \mathrm{~m} \cdot 0.25 \mathrm{~mm}$ ). Helium was used as the carrier gas (linear gas velocity $20 \mathrm{~cm} \cdot \mathrm{s}^{-1}$ ).

Propylene glycol was sampled in XAD-7 tubes and desorbed with $1.5 \mathrm{ml}$ of distilled water. This solution was analyzed by gas chromatography (HewlettPackard 5880A with a flame ionization detector). A capillary column ( $30 \mathrm{~m} \cdot 0.54 \mathrm{~mm}$ internal diameter) coated with DB-wax was used with helium as the carrier gas (flow rate $12 \mathrm{ml} \cdot \mathrm{min}^{-1}$ ).

Qualitative analyses of the air above the eight experimental paints served as a guide for the major analyses. Paint samples of about $20 \mathrm{~g}$ were put into $75-\mathrm{ml}$ twist cap vials, which were heated to $50^{\circ} \mathrm{C}$. With a gastight syringe $(1 \mathrm{ml})$, head-space samples were withdrawn and analyzed with gas chromatography-mass spectrometry (Varian 3400/INCOS 50). The gas chromatograph was equipped with a capillary column ( $25 \mathrm{~m} \cdot 0.25 \mathrm{~mm}$ internal diameter) coated with a DB5 stationary phase. These analyses showed that the declared volatile solvents could be detected. No
Table 3. Average concentrations of various components in the paints according to the declaration and the time-weighted average concentrations of the corresponding air contaminants in the inspired air when the paints were applied by the subjects (ammonia and triethyl amine in ppm).

\begin{tabular}{|c|c|c|c|c|c|}
\hline & \multicolumn{2}{|c|}{ Ammonia } & \multicolumn{2}{|c|}{$\begin{array}{c}\text { Triethyl } \\
\text { amine }\end{array}$} & \multirow{2}{*}{$\begin{array}{c}\text { Dibutyl } \\
\text { phthaiate } \\
\text { (Average) }\end{array}$} \\
\hline & Average & SD & Average & SD & \\
\hline \multicolumn{6}{|l|}{ Paint 1} \\
\hline $\begin{array}{l}\text { Paint (\%) } \\
\text { Air (ppm) }\end{array}$ & $0 . \overline{38}$ & 0.13 & - & $\dot{.}$ & - \\
\hline \multicolumn{6}{|l|}{ Paint 2} \\
\hline $\begin{array}{l}\text { Paint (\%) } \\
\text { Air }(\mathrm{ppm})\end{array}$ & $0 . \overline{42}$ & 0.22 & - & $:$ & $\overline{-}$ \\
\hline \multicolumn{6}{|l|}{ Paint 3} \\
\hline $\begin{array}{l}\text { Paint (\%) } \\
\text { Air (ppm) }\end{array}$ & $\begin{array}{l}0.22 \\
0.82\end{array}$ & 0.21 & - & : & 2 \\
\hline \multicolumn{6}{|l|}{ Paint 4} \\
\hline $\begin{array}{l}\text { Paint (\%) } \\
\text { Air (ppm) }\end{array}$ & $\begin{array}{l}0.3 \\
0.64\end{array}$ & 0.15 & - & : & 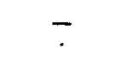 \\
\hline \multicolumn{6}{|l|}{ Paint 5} \\
\hline $\begin{array}{l}\text { Paint (\%) } \\
\text { Air (ppm) }\end{array}$ & $\begin{array}{l}0.34 \\
8.6\end{array}$ & 3.4 & - & : & $\overline{-}$ \\
\hline \multicolumn{6}{|l|}{ Paint 6} \\
\hline $\begin{array}{l}\text { Paint (\%) } \\
\text { Air (ppm) }\end{array}$ & $\begin{array}{l}0.53 \\
6.3\end{array}$ & 2.3 & - & : & $\overline{.}$ \\
\hline \multicolumn{6}{|l|}{ Paint 7} \\
\hline $\begin{array}{l}\text { Paint (\%) } \\
\text { Air (ppm) }\end{array}$ & $8 . \overline{5}$ & 0.86 & - & $\dot{.}$ & - \\
\hline \multicolumn{6}{|l|}{ Paint 8} \\
\hline $\begin{array}{l}\text { Paint (\%) } \\
\text { Air (ppm) }\end{array}$ & $0 . \overline{49}$ & 0.20 & $\begin{array}{l}0.35 \\
0.35\end{array}$ & 0.17 & $\overline{.}$ \\
\hline
\end{tabular}

a Plasticizer (CAS 84-74-2), vapor pressure at $25^{\circ} \mathrm{C}, 0.0019 \mathrm{~Pa}$. 
Table 4. Concentrations of biocides in the paints (according to declaration, ppm of wet paint).

\begin{tabular}{|c|c|c|c|c|c|c|}
\hline Paint & $\begin{array}{c}\text { Chloromethyliso- } \\
\text { thiazolinone }{ }^{a}+ \\
\text { methyliso- } \\
\text { thiazolinone }\end{array}$ & $\begin{array}{c}\text { Benziso- } \\
\text { thiazolinone }\end{array}$ & $\begin{array}{l}\text { Chloroacetic } \\
\text { aldehyded }\end{array}$ & $\begin{array}{l}\text { Hexabutyl } \\
\text { stannoxane }\end{array}$ & $\begin{array}{l}\text { 2,3-Dibromo- } \\
\text { propane } \\
\text { amide }\end{array}$ & $\begin{array}{l}\text { 3-lodine-2- } \\
\text { propynyl } \\
\text { butyl } \\
\text { carbamates }\end{array}$ \\
\hline 1 & 13 & - & - & - & - & - \\
\hline 2 & 10 & 140 & - & - & - & - \\
\hline 3 & - & 200 & - & - & - & - \\
\hline 4 & - & 200 & - & - & - & - \\
\hline 5 & - & 15 & 21 & 18 & 35 & - \\
\hline 6 & - & 15 & 18 & 15 & 35 & - \\
\hline 7 & - & 160 & - & - & - & 900 \\
\hline 8 & - & - & 18 & 15 & 30 & - \\
\hline
\end{tabular}

a -Chloro-2-methyl-4-isothiazolin-3-one (CAS 26172-55-4), approximate vapor pressure at $25^{\circ} \mathrm{C}, 1 \mathrm{~Pa}$.

2-Methyl-4-isothiazolin-3-one (CAS $2682-20-4$ ), approximate vapor pressure at $25^{\circ} \mathrm{C}, 1 \mathrm{~Pa}$.

CAS 2634-33-5, approximate vapor pressure at $25^{\circ} \mathrm{C}, 0.0001 \mathrm{~Pa}$.

CAS 107-20-0.

e CAS 56-35-9.

$t$ CAS 15102-42-8.

g CAS 55406-53-6.

Table 5. Number of symptoms, by type or location, reported by the 18 subjects (nuisance and nonnuisance groups combined) immediately after work with the experimental paints.

\begin{tabular}{lcccccc}
\hline Paint & Eyes & Cough & Stomach & $\begin{array}{c}\text { Head- } \\
\text { ache }\end{array}$ & $\begin{array}{c}\text { Urinary } \\
\text { tract }\end{array}$ & Fatigue \\
\hline 1 & - & - & 1 & 1 & 1 & - \\
2 & - & - & - & - & 1 & - \\
3 & 3 & 1 & - & 1 & 3 & - \\
4 & - & -2 & - & - & 1 & - \\
5 & 2 & - & -2 & 3 & 1 & - \\
6 & 3 & 3 & 2 & 2 & 2 & - \\
7 & 1 & - & - & 2 & - & 1 \\
\hline
\end{tabular}

Table 6. Factor loadings (correlation coefficients between variables and factors) in the factor analysis of exposure variables. Loadings $>0.5$ in italics.

\begin{tabular}{|c|c|c|c|c|}
\hline \multirow{2}{*}{$\begin{array}{l}\text { Original } \\
\text { variable }\end{array}$} & \multicolumn{4}{|c|}{ Factor } \\
\hline & 1 & 2 & 3 & 4 \\
\hline Hexylene glycol & 0.213 & 0.867 & 0.133 & 0.163 \\
\hline Texanol & 0.614 & 0.254 & 0.125 & 0.190 \\
\hline Dalpad A & 0.709 & 0.014 & 0.173 & 0.278 \\
\hline Propylene glycol & 0.035 & 0.239 & 0.923 & 0.114 \\
\hline $\begin{array}{l}\text { Lusolvan } \mathrm{FBH}^{\mathrm{a}} \text { and } \\
\text { I-propynyl butyl } \\
\text { carbamate }^{\mathrm{b}}\end{array}$ & 0.875 & 0.133 & -0.349 & 0.037 \\
\hline Dibutyl phthaiate & -0.451 & 0.347 & -0.407 & 0.344 \\
\hline $\begin{array}{l}\text { Chloromethylisothia- } \\
\text { zolinone and methyl- } \\
\text { isothiazolinone }\end{array}$ & -0.232 & -0.368 & -0.169 & -0.806 \\
\hline Benzisothiazolinone & 0.099 & 0.960 & -0.071 & -0.095 \\
\hline $\begin{array}{l}\text { Chloroacetic aldehyde, } \\
\text { dibromo propane amide } \\
\text { and hexabutyl stannoxan }\end{array}$ & 0.018 & -0.194 & 0.821 & 0.440 \\
\hline $\begin{array}{l}\text { Ammonia + triethyl } \\
\text { amine }\end{array}$ & 0.618 & 0.452 & 0.472 & 0.257 \\
\hline Particulate matter & 0.231 & -0.152 & 0.208 & 0.625 \\
\hline
\end{tabular}

a A mixture of dicarbonic acid esters of isobutanol.

b Lusolvan FBH and I-propynyl butyl carbamate occurred only in paint number 7 .

c Chloromethylisothiazolinone and methylisothiazolinone are components of a combined preparation and occurred together in the same proportions in paints 1 and 2 .

d Chloroacetic aldehyde, dibromo propane amide and hexabutyl stannoxan occurred in almost constant proportions only in paints 5,6 , and 8 . monomers of the binders could be observed in any of the samples.

The concentration of biocides or dibutyl phthalate in the air was not measured, since these substances generally have low vapor pressures. Finally, we measured the temperature and relative humidity with a thermohygrograph.

\section{Results}

In the initial inquiry 71 house painters, or $35 \%$ of those responding, said that they felt nuisance from their work with paints. Twenty-five painters, or $12 \%$ of those answering the inquiry, complained about waterborne paints. The complaints referred to were, for example, headache, stomach trouble, and excess urination.

The complaints reported after each experiment are displayed in table 5. Altogether 48 complaints were noted. Forty of these complaints came from the nuisance group and only eight from the nonnuisance group. The number of symptoms reported before work was insignificant.

The average concentrations of contaminants in the inspired air are presented in tables $1-3$. To consider any exposure-effect associations with low volatile paint components not measured as air contaminants, the declared content of the paint (in parts per million or percentage of paint weight) was used. This procedure was based on the assumption that a possible uptake of these components may be mediated by the particles generated in the painting operation or by skin absorption from contact with the paint (eg, by splashes). This possible uptake was assumed to be proportional to the content of the substances in the paints.

Since the exposure was complicated by the presence of more than one substance in each experiment and some of them were correlated, the exposure variables were subjected to factor analysis. The purpose of a factor analysis is to describe the covariance relationships 
among many variables in terms of a few underlying quantities called factors. The factor model used was leading to a set of uncorrelated factors. The observed variables are linear functions of the factors. The weighing coefficient, or loading of each variable on a factor, is also the correlation coefficient of the variable with the factor $(17,18)$.

Before the factor analysis the variables were transformed to their logarithms, after zero readings of the original variables had been set to a low value, 0.0001 . The variables were then standardized by subtracting the mean of every variable and dividing the difference by the standard deviation. Standardization avoids the problems of having one variable with a large variance unduly influencing the factor loadings. On the other hand, before the potency of the substances can be judged, the true variances must be considered as well.

The variables "paint consumption" and "relative humidity during the experiments" contributed nonsignificantly to the total variability and were therefore removed from further analyses. By the factor analysis the remaining 11 exposure variables (the sum of ammonia and triethyl amine was used in the experiment with paint number 8 ) were reduced to four factors, explaining $87.6 \%$ of the total variability. The number of factors in the model was equal to the num- ber of eigenvalues greater than one, according to a simple convention (17). In this connection the eigenvalues measured the variation accounted for by each factor.

The four factors were rotated (transformed) according to the varimax method. The goal of the rotation was to ensure that each variable loaded highly on a single factor and had small-to-moderate loadings on the remaining factors (17). The standard scores of the factors were the estimates of the values for the factors. The standard scores of the factors were used instead of the original exposure variables in further analyses. The factor loadings of the original variables on these four factors are presented in table 6.

The initial values of the effect variables were used as individual reference values in all of the variance analyses except for urine excretion and urine density. In the latter two cases, work stress was expected to influence the variables. Therefore, the averages for each subject in all of the experiments were used as references. The initial size of some of the effect variables is presented in table 7 , with a comparison between the nuisance group and the nonnuisance group.

In figures $1-5$ the results of the analyses of variance of some of the effect variables are presented. No interactions of the repetitions of the experiments contradicted the results.

Table 7. Base-line values of some of the effect variables for the eight subjects belonging to the nonnuisance group and the 10 subjects belonging to the nuisance group. ( $F V C=$ forced vital capacity, $F E V_{1.0}=$ forced expiratory volume in $1 \mathrm{~s}, P E F=$ peak expiratory flow, MCV = mean corpuscle volume)

\begin{tabular}{|c|c|c|c|c|c|c|c|c|c|c|c|c|}
\hline \multirow[t]{2}{*}{ Group } & \multicolumn{2}{|c|}{$\underset{\text { (I) }}{\mathrm{FVC}}$} & \multicolumn{2}{|c|}{$\begin{array}{l}\mathrm{FEV}_{1 . P} \\
\left(I \cdot \mathrm{s}^{-i}\right)\end{array}$} & \multicolumn{2}{|c|}{$\begin{array}{c}\text { PEF } \\
\left(1 \cdot s^{-1}\right)\end{array}$} & \multicolumn{2}{|c|}{$\begin{array}{c}\text { Urine } \\
\text { density } \\
\left(\left.g \cdot\right|^{-1}\right)\end{array}$} & \multicolumn{2}{|c|}{$\begin{array}{l}\text { Urine } \\
\text { excretion } \\
\text { (ml) }\end{array}$} & \multicolumn{2}{|c|}{$\begin{array}{l}\mathrm{MCV} \\
\left(\mu \mathrm{m}^{3}\right)\end{array}$} \\
\hline & Mean & SD & Mean & SD & Mean & $S D$ & Mean & SD & Mean & SD & Mean & SD \\
\hline $\begin{array}{l}\text { Nonnuisance } \\
\text { Nuisance }\end{array}$ & $\begin{array}{l}5.23 \\
5.86\end{array}$ & $\begin{array}{l}0.77 \\
0.61\end{array}$ & $\begin{array}{l}4.44 \\
4.14\end{array}$ & $\begin{array}{l}0.55 \\
0.78\end{array}$ & $\begin{array}{l}6.27 \\
6.15\end{array}$ & $\begin{array}{l}0.78 \\
1.46\end{array}$ & $\begin{array}{l}1022 \\
1021\end{array}$ & $\begin{array}{l}5 \\
6\end{array}$ & $\begin{array}{l}214 \\
369.1\end{array}$ & $\begin{array}{r}93 \\
262\end{array}$ & $\begin{array}{l}89.6 \\
89.4\end{array}$ & $\begin{array}{l}3.9 \\
2.9\end{array}$ \\
\hline P-value & \multicolumn{2}{|c|}{0.06} & \multicolumn{2}{|c|}{$>0.1$} & \multicolumn{2}{|c|}{$>0.1$} & $>0$. & & \multicolumn{2}{|c|}{$>0.1$} & \multicolumn{2}{|c|}{$>0.1$} \\
\hline
\end{tabular}

a After exposure to paint 1 .

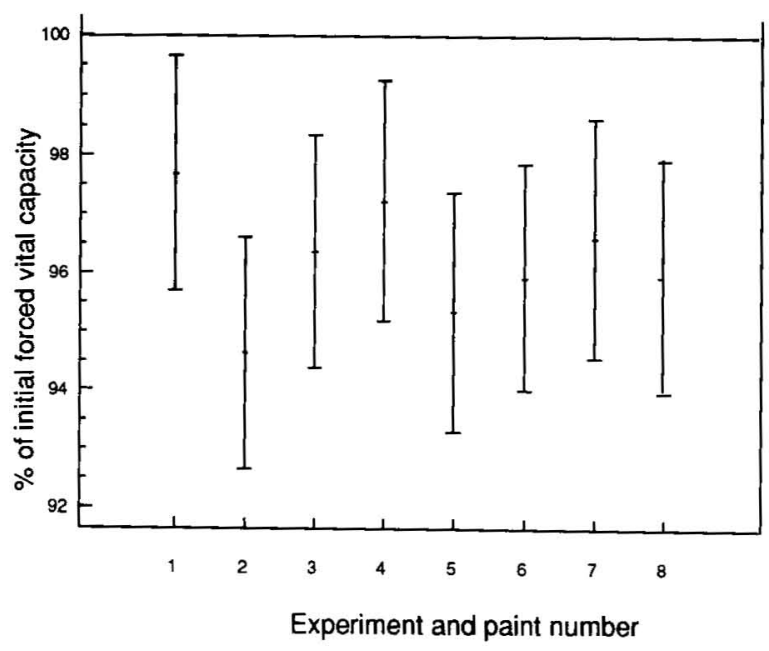

Figure 1. Analysis of variance of forced vital capacity as the percentage of the initial afternoon values of the subjects after exposure to the eight experimental paints. The $95 \%$ confidence intervals are marked in the figures. There were no statistically significant differences between the experiments. 


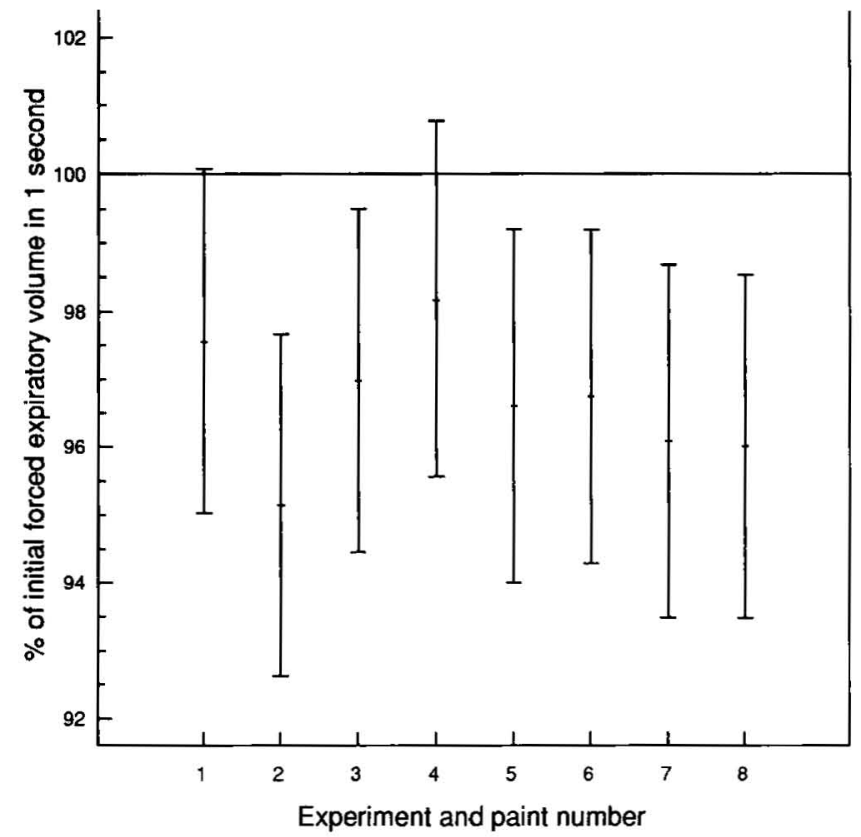

Figure 2. Analysis of variance of forced expiratory volume in $1 \mathrm{~s}$ as the percentage of the initial afternoon values of the subjects after exposure to the eight experimental paints. The $95 \%$ confidence intervals are marked in the figures. There were no statistically significant differences between the experiments.

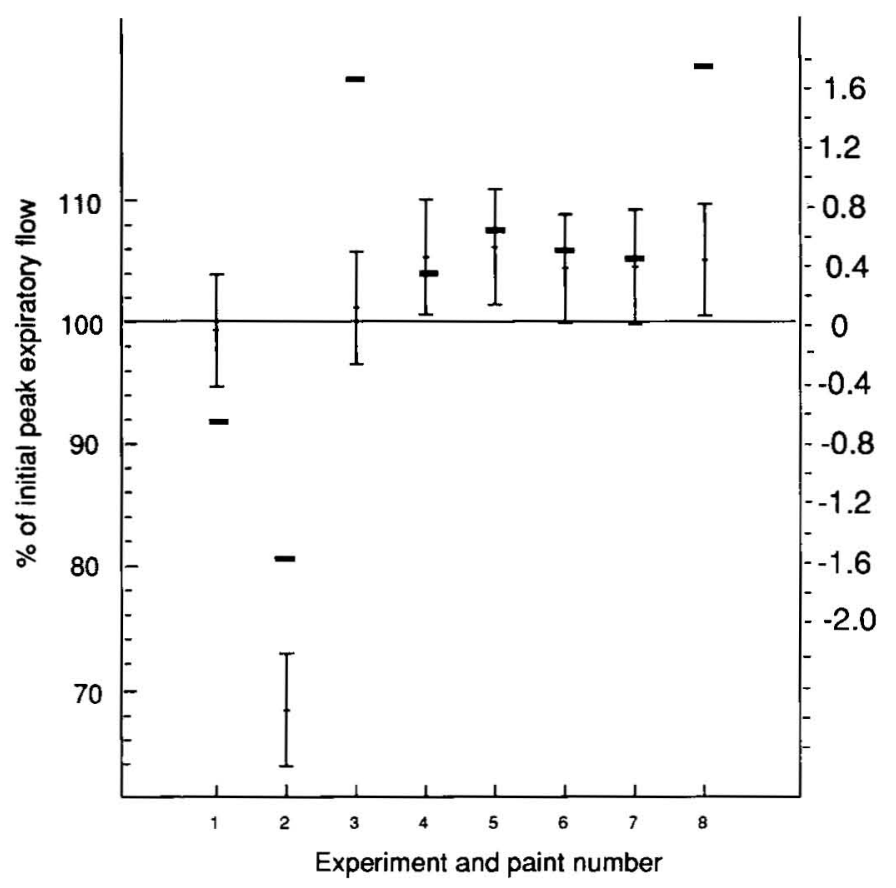

Figure 3. Analysis of variance of peak expiratory flow as the percentage of the initial afternoon values. Probability of no difference between experiments $P=$ 0.001 . The exposure factor showing the best fit with average effects is factor 4 dominated by chloromethylisothiazolinone + methylisothiazolinone (correlation coefficient $0.75, \mathrm{~N}=8, \mathrm{P}=0.03$ ). The average standard scores of factor 4 are shown as bold dashes in reference to the scale on the right axis.

Although there was a general decrease in FVC and $\mathrm{FEV}_{1.0}$ (figures 1 and 2), there were no significant differences in the effects on these variables between the eight experiments. There were no effects on the level of leucocytes, reticulocytes and thrombocytes, the hemoglobin concentration, the content of hemoglobin, or the mean corpuscle concentration of hemoglobin in the erythrocytes. Nor were there any effects on the bilirubin, aspartate aminotransferase and alanine aminotransferase levels. There were no effects on the plasma content of haptoglobin or the immunoglobulin (IgE, IgA, IgM, IgG) levels. The mean blood pressure and the electrocardiographic variables were not affected either. There were no effects on the abdomen measure.

Simple linear regression analyses were carried out for effect variables on exposure data for all of the eight experiments and for each study person separately. In 


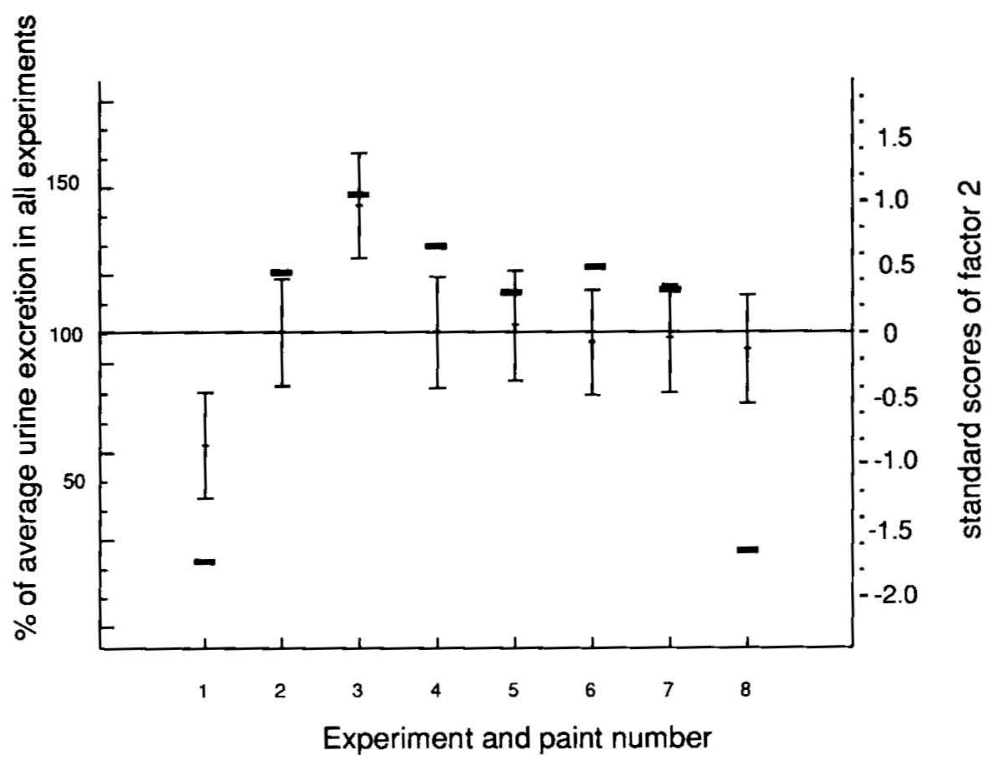

Figure 4. Analysis of variance of urine excretion as the percentage of urine excretion of the respective subject in all of the experiments. Probability of no difference between experiments $P<0.0001$. The exposure factor showing the best fit with the average effects is factor 2 , dominated by benzisothiazolinone and hexylene glycol (correlation coefficient 0.84 , $\mathrm{N}=8, \mathrm{P}=0.009$ ). The average standard scores of factor 2 are shown as bold dashes in reference to the scale on the right axis.

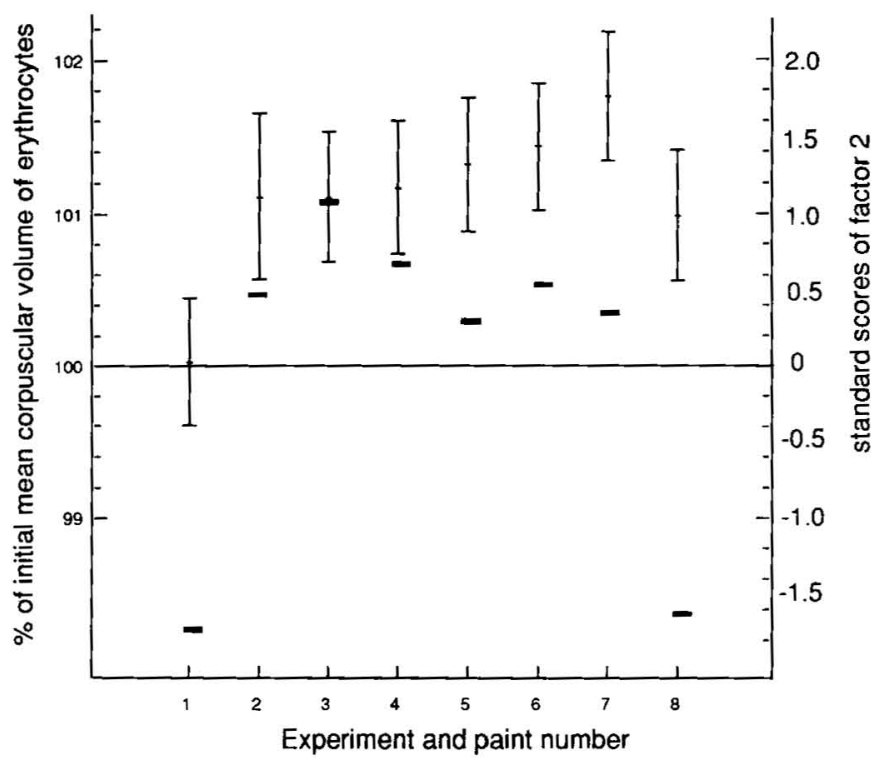

Figure 5. Analysis of variance of mean corpuscular volume of the erythrocytes as the percentage of the initial values. Probability of no difference between experiments $P=0.006$. The exposure factor showing the best fit with average effects is factor 2 , dominated by benzisothiazolinone and hexylene glycol (correlation coefficient $0.66, \mathrm{~N}=8, \mathrm{P}=0.08$ ). The average standard scores of factor 2 are shown as bold dashes in reference to the scale on the right axis. these analyses the effect variables were used directly, since division of a variable by the same reference value would not influence the analysis. In table 8 the results of 360 such regression analyses are summarized. The slopes in table 8 have the size variable units per standard score unit and are therefore comparable.

\section{Discussion}

The observed effects were small, except for that on urine excretion, and temporary in nature. The effects studied were probably eliminated in the course of a few days without exposure. The reason for this assumption is that the subjects were normally exposed to the same types of paints in their work the week before each exposure study, yet the effects were discernable in the experiments.

\section{Symptoms}

The symptoms experienced during the experiments were few (table 5). On the average one-third of the subjects had a symptom in every experiment. This may be a healthy worker effect, since painters that suffer too much from exposure probably quit work in the trade. There was a tendency for the symptoms to increase in experiments with the paints that emitted the highest concentrations of ammonia (paint numbers 5 , 
Table 8. Average slopes (b) of the regression equations of 18 subjects in the analyses of effect variables on exposure variables (factor scores from factor analysis, table 6). Size of slopes: variable units per standard score unit (u). Probabilities (P-values, 2 -sided) $\leq 0.050$ in Student's t-tests for the zero hypothesis: average slope $=0$. The original variable with the highest loading on a factor is indicated in parentheses.

\begin{tabular}{|c|c|c|c|c|}
\hline \multirow[b]{2}{*}{ Effect variables } & \multicolumn{4}{|c|}{ Exposure variables } \\
\hline & $\begin{array}{l}\text { Scores of factor } 1 \\
\text { (Lusolvan } \mathrm{FBH}^{\mathrm{a}} \text { and } \\
\text { l-propynyl butyl } \\
\text { carbamate) }\end{array}$ & $\begin{array}{l}\text { Scores of factor } 2 \\
\text { (benziso- } \\
\text { thiazolinone) }\end{array}$ & $\begin{array}{l}\text { Scores of factor } 3 \\
\text { (propylene glycol) }\end{array}$ & $\begin{array}{l}\text { Scores of factor } 4 \\
\text { (methyliso- } \\
\text { thiazolinones) }\end{array}$ \\
\hline $\begin{array}{l}\text { Forced vital ca- } \\
\text { pacity (I) }\end{array}$ & $\mathrm{b}=0$ & $\begin{array}{l}b=-0.0200 \mathrm{I} \cdot \mathrm{u}^{-1} \\
P=0.04\end{array}$ & $b=0$ & $b=0$ \\
\hline $\begin{array}{l}\text { Peak expiratory } \\
\text { flow }\left(1 \cdot s^{-1}\right)\end{array}$ & $\begin{array}{l}b=0.264 I \cdot\left(s^{*} u\right)^{-1} \\
P<0.0001\end{array}$ & $\begin{array}{l}b=-0.103 \mathrm{I} \cdot\left(\mathrm{s}^{*} \mathrm{u}\right)^{-1} \\
\mathrm{P}=0.03\end{array}$ & $\begin{array}{l}b=0.133 I \cdot\left(s^{\star} u\right)^{-1} \\
P=0.003\end{array}$ & $\begin{array}{l}b=0.532 I \cdot\left(s^{\star} u\right)^{-1} \\
P<0.0001\end{array}$ \\
\hline $\begin{array}{l}\text { Urine excretion } \\
(\mathrm{ml})\end{array}$ & $\begin{array}{l}\mathrm{b}=-49.0 \mathrm{ml} \cdot \mathrm{u}^{-1} \\
\mathrm{P}=0.01\end{array}$ & $\begin{array}{l}\mathrm{b}=91.5 \mathrm{~m} \cdot \mathrm{u}^{-1} \\
\mathrm{P}=0.0003 \\
\mathrm{~b}_{\text {nuisance }}=96.7 \\
\mathrm{~b}_{\text {nonnuisance }}=50.9 \\
\mathrm{P}_{\text {difference }}=0.04\end{array}$ & $b=0$ & $\begin{array}{l}\mathrm{b}=36.1 \mathrm{~m} \cdot \mathrm{u}^{-1} \\
\mathrm{P}=0.02\end{array}$ \\
\hline $\begin{array}{l}\text { Urine density } \\
\left(g \cdot I^{-1}\right)\end{array}$ & $b=0$ & $\begin{array}{l}b=-1.37 \mathrm{~g} \cdot\left(I^{\star} \mathrm{u}\right)^{-1} \\
P=0.0001\end{array}$ & $b=0$ & $\begin{array}{l}\mathrm{b}=-0.617 \mathrm{~g} \cdot\left(1^{\star} \mathrm{u}\right)^{-1} \\
P=0.02\end{array}$ \\
\hline \multicolumn{5}{|l|}{$\begin{array}{l}\text { Mean corpus- } \\
\text { cular }\end{array}$} \\
\hline $\begin{array}{l}\text { volume of } \\
\text { the erythro- } \\
\text { cytes } \\
\left(\mu \mathrm{m}^{3}\right)\end{array}$ & $\begin{array}{l}b=0.211 \mu \mathrm{m}^{3} \cdot u^{-1} \\
P=0.001\end{array}$ & $\begin{array}{l}\mathrm{b}=0.347 \mu \mathrm{m}^{3} \cdot \mathrm{u}^{-1} \\
\mathrm{P}<0.0001\end{array}$ & $b=0$ & $\begin{array}{l}\mathrm{b}=0.242 \mu \mathrm{m}^{3} \cdot \mathrm{u}^{-1} \\
P=0.05 \\
b_{\text {nuisance }}=0.505 \mu \mathrm{m}^{3} \cdot \mathrm{u}^{-1} \\
\mathrm{~b}_{\text {nonnuisance }}=-0.087 \mu \mathrm{m}^{3} \cdot \mathrm{u}^{-1} \\
P_{\text {difference }}=0.001\end{array}$ \\
\hline
\end{tabular}

a A mixture of dicarbonic acid esters of isobutanol.

6 , and 7), while some of the measured effects were indicated to be associated with other substances.

\section{Exposure-effect associations}

The study design was a compromise between the need to keep the number of experiments as few as possible and each experimental exposure as simple as possible. The exposure situation was more complex than planned, however, due to difficulties in obtaining paint products of a predetermined composition. Moreover, the air contaminants did not always relate to the declared content of the paints. Ammonia was present in the air in experiments with paints 1, 2, 7, and 8; see table 3 . According to the declaration, ammonia was not a component of these paints. In many cases solvents were emitted from earlier paint layers and evaporated during later experiments in the series (table 2).

With the use of factor analysis the correlations between the exposure variables could be surveyed and accounted for in a clear way. It was not possible, however, to draw conclusions from the analysis regarding substances that had low loadings on all factors. This was true for dibutyl phthalate in the four factors chosen.

The variance of relative humidity was small in these experiments, and it was therefore not possible to tell whether increased humidity was associated with the increase in urine volume.

Figures 3-5 show some immediate exposure-effect associations. The correlations illustrated can only serve as initial signs of possible associations. The slope in each regression equation of effect on exposure (table 8) can be looked upon as a combined measure. This combined measure shows how a subject reacted to changes in exposure to a factor. An average slope significantly different from zero indicates that the subjects reacted similarly to changes in the exposure.

\section{Lung function}

The PEF decreased substantially, in both repetitions, but only after exposure to paint number 2 . The decrease in PEF was associated with factor 4 (table 8). The dominating variable in factor 4 , the combination chloromethylisothiazolinone plus methylisothizolinone, had a negative loading on the factor. Therefore, a decrease in PEF was indicated to be associated with an increase in the concentration of the methylisothiazolinones in the paints. The decrease in PEF was associated with an increase in factor 2 as well, in which benzisothiazolinone and hexylene glycol dominated. It is unlikely that this association was due to hexylene glycol. Irritation is one of the most important critical effects in the setting of hygienic standards for organic solvents in workplaces (19). Yet acute, temporary effects of organic soivents on lung function have not been reported in the literature. Moreover, propylene glycol, chemically homologous to hexylene glycol and the dominating variable of factor 3 , was not indicated to be associated with any effect on PEF in this study. The concentrations of propylene glycol in the experiments were of the same order of magnitude as those of hexylene glycol. In conclusion, a decrease in PEF 
occurred only when methylisothiazolinones and benzisothiazolinone were present together. The possibility of an additive or synergistic effect between these substances should be investigated.

PEF is an index of the airway caliber of the upper and central airways (12). The acute, temporary effects reported in this study may have been due to acute bronchial constriction. In this connection it may be of interest to consider recent studies on allergic reactions (eg, contact dermatitis) in subjects with exposure to isothiazolinone derivatives (4-8).

The FVC and FEV ${ }_{1.0}$ decreased in all of the experiments when compared with their base-line values (figures 1 and 2). These lung function variables are not lowered by mere physical work in morning or day shifts $(20,21)$. A temporary decrease in these variables has been reported to be associated with exposure to irritating substances. A decrease in FVC over a shift is, for example, reported to be associated with exposure to diesel engine exhausts (22) and a decrease in $\mathrm{FEV}_{1.0}$ over a work week has been reported to be associated with mold exposure in a sawmill (23).

The average decreases in FVC and $\mathrm{FEV}_{1.0}$ were not significantly different in the series of experiments, and the decrease in $\mathrm{FEV}_{1.0}$ was not associated with any factor. The regression analyses established an association between FVC and factor 2, however (table 8). The dominating substances in factor 2 were benzisothiazolinone and hexylene glycol. As has already been discussed, hexylene glycol could probably not have affected the measured lung function variables. There was an indicated association with almost statistical significance $(P=0.06)$ between the decrease in FVC and factor 4 for the nonnuisance group, a result implying an effect of the methylisothiazolinones. The decrease in FVC in experiment 8 needs explanation since paint number 8 did not contain isothiazolinones. The volatilities of these isothiazolinones are low (vapor pressure $1 \mathrm{~Pa}$ ), but it cannot be excluded that effective concentrations of these substances evaporated in later experiments from the accumulated paint layers. This possibility should be tested in other experiments. In conclusion, the decrease in FVC was probably associated with the presence of isothiazolinones in various combinations.

Reports about irritation from isothiazolinones were not found in the literature. [Unpublished animal (rat) exposure studies of an aerosol containing the combination chloromethylisothiazolinone and methylisothizolinone indicate "sensory irritation" at $2.64 \mathrm{mg}$. $\mathrm{m}^{-3}$ of active ingredient (Rohm and Haas Co).]

We did not find any indication of a relationship between the lung function decrease and exposure to ammonia in this study. This result is in agreement with that of another study of acute exposure effects (24). The lung function of 52 workers was measured after a work week and compared with the values before the week. The workers were exposed to an average ammonia concentration of $9.2 \mathrm{ppm}$ in a chemical plant.

\section{Urine excretion}

There was an increase in excreted urine in experiments 2-8 when a comparison was made with the level excreted during work with paint number 1 (figure 4). The increased urine excretion during exposure to paint 3 was substantial, between twice and three times as large as the excretion after exposure to paint number 1 . The urine densities were reflected images of the urine excretion (the correlation coefficient between the averages of urine excretion and the averages of urine densities in the eight experiments being -0.95). The increase in urine excretion was associated with factor 2 with high significance $(P=0.0003)$. There was a difference between the nuisance and the nonnuisance groups. The nuisance group excreted twice as large a urine volume as the nonnuisance group per standard score unit of this exposure factor.

Factor 2 was dominated by benzisothiazolinones and hexylene glycol. The chemical analogy with propylene glycol, dominating in factor 3 , which was not related to urine excretion, makes the association with hexylene glycol less probable. The effect was, therefore, indicated to be due to benzisothiazolinone. The increased urine excretion after exposure in experiment number 8 was considered in the same way as in the discussion on decrease in FVC.

The association with factor 4 implied a negative correlation with the methylisothizolinones. However, this relation also implied an association with particles (containing the preservatives and other low volatile substances).

We have not found any reports in the literature on high increases in urine excretion, as observed in the present study, but the results are in accordance with the workers' own experiences. Proteinuria has been observed in workers exposed to water-borne paints (25).

An increase in mean blood pressure was associated with an increase in urine excretion. The average slope of the regression equations of the mean blood pressure on urine excretion differed from zero in Student's t-test $(P=0.002)$. It has been suggested that exposure to water-borne paints could affect the kidneys and the urinary tract, but no mechanism for this activity was offered (9). The objective of this study was not to explain the mechanisms of the effects, however. Therefore, we did not control the intake of drinks, although the subjects were asked to drink as they usually did. Yet, a possible explanation for the complex effect pattern on urine excretion and the association with the mean blood pressure, suggesting further investigation, is that one or more components in the paints influence the water balance of the body, either by increasing thirst or by temporarily affecting urine excretion only.

\section{Mean corpuscular volume of the erythrocytes}

The variance analysis showed that the mean corpuscular volume of the erythrocytes increased in the experiments with paints $2-8$ (figure 5 ). The effect can 
hardly be due to physical work, since the mean corpuscular volume was not influenced in the first experiment. A difference in the effect between the nuisance and nonnuisance groups is shown as well in table 8 . The changes in mean corpuscular volume may indicate a peripheral, toxic effect on the blood. The changes were associated with three of the factors, and it is hardly possible to attribute the effect to any substance in particular.

A chronically increased erythrocyte volume has been reported for house painters using epoxy resins and for car repair painters $(10,11)$. The authors of these reports could not attribute the effects to special substances.

\section{Concluding remarks}

The subjects in this investigation had few symptoms after exposure to experimental water-borne paints containing components typical of commercial products. Yet we found a temporary decrease in some lung function variables, an increase in urine excretion, and an increase in mean corpuscular volume of the erythrocytes associated with the exposure. The ultimate purpose of the investigation was to guide product development of water-borne paints. It is therefore important to state that the effects on the lungs and on urinary excretion were probably not associated with any of the organic solvents or ammonia in the paints. Instead the effects were indicated to be associated with the presence of isothiazolinones, added as preservatives to the paints, but the attribution of the effects of these substances needs verification.

\section{Acknowledgments}

A grant from the Swedish Council for Building Research financed the work.

In the planning we received advice from representatives of the Trade Union of House painters and the Employers' Association of Master House Painters. Moreover, Mr C-E Anstenius at Alcro-Beckers AB was of great help in designing the experimental paints. This company supplied the experimental paints. Mr U Svedberg and Ms I Koivusalo at the Department of Occupational Health of the Sundsvalls Hospital participated in the exposure measurements. The electrocardiographic measurements and interpretations were carried out by $\mathrm{G}$ Sundström, MD, and the blood analyses were made by A Hamfelt, MD, and Ms E Skrabb, all at the Sundsvalls Hospital.

\section{References}

1. Cranmer JM, ed. Proceedings of the workshop on neurobehavioral effects of solvents. Neurotoxicology 1985; 7(4): $1-123$.

2. World Health Organization (WHO). Solvents and the central nervous system - core protocol. Copenhagen: WHO Regional Office for Europe, 1989:2-3. (Environ- mental health; no 36 .)

3. Hansen MK, Larsen M, Cohr K-H. Water-borne paints: a review of their chemistry and toxicology and the results of determinations made. Scand J Work Environ Health 1987;13:473-85.

4. Brown R. Two cases of occupational allergy to Kathon 886. Contact Dermatitis 1990;23(2):116.

5. Pilger C, Nethercott JR, James R, Weksberg F. Allergic contact dermatitis due to a biocide containing 5-chloro-2-methyl-4-isothiazolin-3-one. Contact Dermatitis $1986 ; 14(4): 201-4$

6. Alomar A. Contact dermatitis from benzisothiazolinone in cutting oils. Contact Dermatitis 1981;7(3):155-6.

7. Roberts DL, Messenger AG, Summerly R. Occupational dermatitis due to 1,2-benzisothiazolin-2-one in the pottery industry. Contact Dermatitis $1981 ; 7(3): 145-7$.

8. Slovak AJM. Contact dermatitis due to benzisothiazolinone in a works analytical team. Contact Dermatitis 1980;6(3):187-90.

9. Askergren A, Beving H, Hagman M, Kristensson J, Linroth $\mathrm{K}$, Vesterberg $\mathrm{O}$, et al. Biologiska effekter av exponering för vattenbaserade och lösningsmedelsbaserade färger hos målare [Biologic effects of exposure to waterborne and solvent based paints in house painters]. Solna (Sweden): National Institute of Occupational Health, 1988:1-64. (Arbete och Hälsa 1988;4.) (English abstract.)

10. Beving H, Malmgren R, Petrén S, Vesterberg O. Haematological changes in house painters using epoxy paints. J Soc Occup Med 1991;41:102-6.

11. Beving $H$, Tornling $G$, Olsson $P$. Increased erythrocyte volume in car repair painters and car mechanics. $\mathrm{Br} \mathrm{J}$ Ind Med 1991;48:499-501.

12. Cotes JE, Peslin R, Yernault JC. Dynamic lung volumes and forced ventilatory flow rates. Bull Eur Physiopathol Respir 1983;19 suppl 5:22-7.

13. Gardner RM. ATS statement - snowbird workshop on standardization of spirometry. Am Rev Respir Dis 1979; 119:831-8.

14. Rose GA, Blackburn H. Cardiovascular survey methods. Geneva: World Health Organization, 1968. (WHO monograph series; no 56.)

15. Rudling J, Hallberg B-O, Hultengren M, Hultman A. Development and evaluation of field methods for ammonia in air. Scand J Work Environ Health 1984;10: 197-202.

16. Hallberg B-O, Hansén L, Nilsson-Hagelroth A-M. Metoder för bestämning av tertiära aminer i luft [Methods for determination of tertiary amines in air]. Solna (Sweden): Division of Analytical Chemistry, National Institute of Occupational Health, 1991:1-10. (Investigation report; no 16.)

17. Johnson RA, Wichern DW. Applied multivariate statistical analysis. 2nd edition. London: Prentice-Hall International (UK) Limited, 1988:378-422.

18. Fergusson GA. Statistical analysis in psychology and education. 5th edition. New York, NY: McGraw-Hill Book Company, 1981:496.

19. Ulfvarson U. Assessment of concentration peaks in setting exposure limits for air contaminants at workplaces, with special emphasis on narcotic and irritative gases and vapors. Scand J Work Environ Health 1987;13:389-98.

20. Dimich HD, Sterling TD. Ventilatory function changes over a work shift. Br J Ind Med 1981;38:152-5.

21. Love RG. Lung function studies before and after a work shift. Br J Ind Med 1983;40:153-9.

22. Ulfvarson $\mathbf{U}$, Alexandersson $\mathbf{R}$. Reduction in adverse effect on pulmonary function after exposure to filtered diesel exhaust. Am J Ind Med 1990;17:341-7.

23. Dahlqvist M, Johard U, Alexandersson R, Bergström B, Ekholm U, Eklund A, et al. Lung function and precipitating antibodies in low exposed wood trimmers in Sweden. Am J Ind Med 1992;21:4:549-59. 
24. Holness DL, Purdham JT, Nethercott JR. Acute and chronic respiratory effects of occupational exposure to ammonia. Am Ind Hyg Assoc J 1989;50:12:646-50.

25. Kristensson J, Beving H. A study of painters occupationally exposed to water and solvent based paints. In: Berlin A, Brown RH, Sunders KJ, ed. Diffusive sampling: an alternative approach to workplace air moni- toring: proceedings of an international symposium, Luxembourg, 22-26 September 1986, London. London: Royal Society of Chemistry, 1987.

Received for publication: 22 July 1991 